\title{
SHARI'AH BYLAWS IN INDONESIA AND THEIR IMPLICATIONS FOR RELIGIOUS MINORITIES
}

\author{
Ahmad Fuad Fanani \\ Flinders University, Australia
}

\begin{abstract}
This article examines the implementation of shari'ah bylaws as a response to the regional autonomy law passed in 1999 and their implications for religious minorities. Under this regional autonomy regulation, local governments at the district level have authority to issue their own regulations. There are three broad sets of issues in Indonesian shari'ah bylaws: public order and social problems, religious skills and obligations, and religious symbolism. The article argues that the introduction of such bylaws has many negative implications for religious minorities in Indonesia. This is, it further argues, because many of religious minority groups are forced to observe the same regulations as mainstream Muslims. Shari'ah bylaws, it goes on to say, have also caused discrimination against religious minorities. Attempts to keep wary eyes on the the negative implications of the enactment of shari'ah bylaws need, therefore, to be undertaken. This responsibility is not in the hands of the government, but also Muslim communities at large. The Indonesian government must treat all social and religious groups equally, guaranteeing no discrimination against each of them. Muslim communities are deeply in need of exploring and practicing the substance, and not the formal aspects, of shari'ah.
\end{abstract}

Keywords: Shari'ah bylaws, religious minorities, Ahmadiyah.

\section{Introduction}

The formalization of shari'ah rules has been the subject of wideranging debate in Indonesia, and also internationally. This is because 
this idea has significant implications, politically and socially, not only for Muslims, but also for followers of other religions who live in Indonesia. Although the majority of Indonesians are Muslims, shari'ah law has not been implemented formally in many regions in Indonesia. However, since the fall of President Soeharto and the New Order in 1998, Indonesia has transitioned from an authoritarian regime to a democracy and undergone decentralization. Since that time, local governments have used their authority to create regional religious regulations (shari'ah bylaws) that regulate religious norms ${ }^{1}$. Many regional authorities and proponents of shari'ah bylaws used the reformasi era to formalize shari'ah at the state level.

It is important to note that 78 shari'ah bylaws have already been ratified by regional authorities. More than 52 cities and regencies have applied these regulations at the regional level. This does not include draft or proposed legislation (raperda) or regent (Bupati) edicts, but does include the implementing regulations (qanun) in $\mathrm{Aceh}^{2}$. In general, these shari'ah bylaws are concerned with three broad sets of issues: public order and social problems (such as prostitution, consumption of alcohol and gambling), religious skills and obligations (such as reading the Qur'an, paying zakat or alms or religious tax, and attending Friday prayers), and religious symbolism (such as the wearing of Muslim clothing). ${ }^{3}$ As Robin Bush writes, these shari'ah bylaws attract significant attention from politicians, public figures, and intellectuals. This is because they raise a number of issues, including constitutional issues, discrimination (many of non Muslim felt threatened about shari'ah bylaws), and governance 4 . The implementation of shari'ah bylaws in Indonesia remains hotly contested.

\footnotetext{
1 Melissa Crouch, "Religious regulations in Indonesia: failing vulnerable groups," Review of Indonesian and Malaysian Affairs, vol. 43, no. 2 (2009), p. 53.

2 Robin Bush, "Regional Sharia Regulations in Indonesia: Anomaly or Symptom?," in G. Fealy and S. White (eds), Expressing Islam: Religious Life and Politics in Indonesia (Singapore: Institute of Southeast Asian Studies, 2008), p. 176.

3 A. Salim, "Muslim Politics in Indonesia's Democratisation: The Religious Majority and the Rights of Minorities in the Post-New Order Era," in R.H. McLeod and A. MacIntyre (eds), Indonesia: Democracy and the Promise of Good Governance (Singapore: Institute of Southeast Asian Studies, 2007), p. 126.

${ }^{4}$ Bush, "Regional Sharia Regulations," p. 175.
} 
Some analysts argue that the enactment of shari'ah bylaws reflects the fact that the majority of the Indonesian population is Muslim. However, others rebut this argument by pointing to the fact that Indonesia is not religious state, but a neutral state which embraces many religious and cultures. Hence, government must protect and promote the rights of all its citizens as well as prevent discrimination. This article examines the implementation of shari'ah bylaws and their implications for religious minorities. Arguing that shari'ah bylaws have a negative impact on religious minorities in Indonesia, it consists of three parts. The first part examines the background of the emergence of shari'ah bylaws. The second part assesses the impact of shari'ah bylaws on religious minorities' rights. The third part provides some suggestions on how to protect the rights of religious minorities.

\section{The Background of the Emergence of Shari'ah Bylaws}

The process of democratization and regional autonomy which has taken place since the fall of the Soeharto regime has had both positive and negative effects for Indonesia. One the one hand, the fall of Soeharto opened many opportunities for Indonesians to be more actively engage in the process of political reform in a democratic way. The event also rebalanced the distribution of power between central and regional government. Before the fall of Soeharto, central government often treated regions as a government branch with no real authority. Then decentralization through regional autonomy became the policy and this made the government more effective, efficient, and democratic. On the other hand, the creation and implementation of shari'ah bylaws (Perda Syariah) in many regions has been one of the 'negative effects' in the country which constitutionally declares itself as a religiously neutral state. This can be seen as an example of Islamic radical groups in Indonesia using democratic processes for an undemocratic purpose.

In this respect, the regional religious regulations or shari'ah bylaws actually emerged as a response to the regional autonomy law which was passed in 1999. Under this new regulation, local governments at the district level have authority to issue their own regulations. The central government cannot intervene in local administration ${ }^{5}$.

${ }^{5}$ Luthfi Assyaukanie, "The Rise of Religious Bylaws in Indonesia," RSIS Commentaries, $(22 / 2007)$. 
The enactment of the Decentralized Law in January 2001 represents a fundamental change in the position and relationship between the central and local governments. But there are many weaknesses in its implementation. This is because the law itself does not make clear how it should be implemented, leaving the relationship between central government and the regions ambiguous. Besides, the Decentralization Law was labeled as contradictory, inadequate, and flawed. ${ }^{6}$ Another weakness was the central government only provided for relatively few checks and balances relevant to the passing of shari'ah bylaws. The enormous power which was given by the central government to local authorities has gone too far, leaving room for the creation of unimportant laws. Ironically, some of the regulations from regions are about religious matters which are actually still under control of central government. Due to the lethargy of the central government to properly address this issue, these laws continue to operate. ${ }^{7}$

Responding to this issue, Michael Buehler points out that the increasing number of the shariah bylaws is not just an indication of a conservative movement within the Indonesian Muslim community. This trend also reveals a change in the pattern of power accumulation and political corruption in Indonesian local politics. ${ }^{8}$ Indeed, as stated by Robin Bush, political leaders have been known to issue shari'ah bylaws as a means of establishing their 'Islamic' credentials among their constituents.9 Many of local political leaders tend to use the autonomy laws to strengthen their position by pandering to the Muslim majority. By demonstrating support for Islam, although it only symbolic, Muslim voters will be easily convinced that these leaders will favor Islamic interests.

The emergence of shari'ah bylaws in many Indonesian regions can also be seen as a new form of the shari'ah movement in Indonesia. This kind of movement emerged after the failure of the formalization of shari'ah in national level. In 2002, the struggle of the implementation of shari'ah at the central level has experienced a

\footnotetext{
${ }^{6}$ Crouch, "Religious Regulations in Indonesia," pp. 55-56.

7 Ibid., p. 56.

${ }^{8}$ M. Buehler, "The rise of Shari'a by-laws in Indonesian Districts: An Indication for Changing Patterns of Power Accumulation and Political Corruption," South East Asia Research, vol. 16, no. 2 (2008), p. 256.
}

9 Bush, "Regional Sharia Regulations," p. 188. 
considerable setback. During deliberations on the process of amending the 1945 Constitution, the People's Consultative Assembly (MPR) rejected a proposal to insert the Jakarta Charter into the Constitution. The Jakarta Charter is an old constitutional amendment which recognised the obligation of Muslims to implement the shari'ah in the country. The main factor behind this failure was a lack of supporters from mainstream political parties. There were only two small Islamic parties (the United Development Party and the Crescent Star Party) supported the proposal. In contrast, the nationalist parties in parliament and major Islamic organizations such as Nahdlatul Ulama' (NU) and Muhammadiyah opposed the idea. ${ }^{10}$ As a result, there is little prospect that shari'ah could ever be formalised at the state level.

The lack of support from other parties in parliament and Islamic organizations toward the notion of the enforcement of shari'ah law closely correlates with the distinctive nature of Indonesian Islam. Although the majority of the Indonesian population is Muslim, the Islamic parties only won a small percentage of the vote and accordingly represent a vocal minority only. For example, in 1999 national election, both Islamic parties (the National Awakening Party and the National Mandate Party) and Islamist parties (the United Development Party, the Justice Party, and the Crescent and Star Party) only took $38 \%$ of the vote. In 2004 the total votes gained by the combination of both the Islamic and Islamist parties were $38 \% .{ }^{11}$ The total votes of the nationalist parties (Democrat Party, Golkar Party and PDI-P Party) outnumbered those of the combination of both the Islamic and Islamist parties. This reminds us of the debate between the Islamicoriented politicians and the leading kebangsaan (nationalist) groups during the formative era in Indonesia. At that time, the nationalist groups won the debate and Pancasila (Five Principles) then became state ideology. ${ }^{12}$ Indeed, Pancasila clearly respects all six dominant religions in Indonesia and gives equal rights to all Indonesian people.

It is important to note that though the struggle of the formalization of shari'ah in national level ended in failure, the proponents of shari.'ah still carry on with their cause. In fact, they use

\footnotetext{
10 Assyaukanie, "The Rise of Religious Bylaws in Indonesia".

${ }^{11}$ Bush, "Regional Sharia Regulations," p. 182.

12 G. Eliraz, Islam in Indonesia: Modernis, Radicalism, and the Middle East Dimension (Brighton \& Portland: Sussex Academic Press, 2004), pp. 78 -79.
} 
local (provincial and district) parliaments, along with the introduction of autonomy packages and direct elections as the strategic way to formalize shari'ah. This has resulted in the enactment of shari'ah bylaws in dozens of provinces and districts throughout Indonesia. ${ }^{13}$ Some national magazines in Indonesia such as Gatra and Tempo reported that the supporters of shari' ah are pursuing a strategy of controlling districts before spreading shari'ah to provincial and national levels. This strategy is described as "from village to city" and promoting shari'ah through the slow lane. ${ }^{14}$ Clearly, the struggle to formalize shari'ah remains alive.

Moreover, the implementation of shari'ah in Aceh has encouraged other regions in Indonesia to follow this success. After the central government allowed Aceh to implement shari'ah through a special autonomy law, other regions began to imitate Aceh by introducing bylaws (perda), decrees (keputusan), instructions (instruksi), and circulars (surat edaran). All of these laws contain Islamic injunctions. ${ }^{15}$ In this regard, it is widely known that Aceh has been the pivotal inspiration and pioneer of the implementation of the shari'ah bylaws in Indonesia. Advocates of shari'ah sought to imitate Aceh's example and insisted that the central government give them the same opportunity. ${ }^{16}$ Although the social, political and historical background of Aceh in implementing shari'ah bylaws is certainly different from other regions, advocates of shari'ah thought that they deserved to have the same rights as Aceh.

\section{The Implications of Shari'ah Bylaws for Religious Minorities}

It has been asserted by the proponents of shari'ah bylaws that because of the majority of Indonesians are Muslims, they have the rights to implement shari'ah rules. They also contend that this

13 N. Hasan, "Islamic Militancy, Shari'a Bylwas, and Democratic Consolidation in Post-Suharto Indonesia," KULTUR: The Indonesian Journal for Muslim Cultures, vol. 4, no. 2 (2009), p. 40.

14 A. E. Hara, "Pancasila and the Perda Syari'ah Debates in the Post-Suharto Era: Toward a New Political Consensus," in O. Atsushi et al. (eds), Islam In Contention: Rethinking Islam and State in Indonesia (Indonesia: The Wahid Institute - Japan: CSEAS Taiwan: CAPAS, 2010), pp. 47-48.

${ }^{15}$ Salim, "Muslim Politics in Indonesia," p. 126

${ }^{16}$ Hasan, "Islamic Militancy, Shari’a Bylwas," p. 43. 
demographic majority gives socio-cultural and political legitimacy to the implementation of Islamic principles as the basis of the state. Another reason for the demand of the implementation shari'ah law is the contribution of Indonesian Muslims to the struggle against Dutch colonial power. Although there are many concerns about discriminations against minority groups in regions where shari'ah has been introduced, they claim that shari'ah is not harmful to minority groups. ${ }^{17}$ In addition, the proponents of shari'ah bylaws also argue that the formalizing of shari'ah has produced positive impacts, including increased security, increased charitable contributions, donations and gifts, and improved levels of religious piety. ${ }^{18}$

However, as Moeslim Abdurrahman has said, when a shari'ah bylaw is imposed, women, non-Muslim, and the poor will become the first victims of this regulation. ${ }^{19}$ This is because they have to follow a rigid interpretation of religious tenets which do not favor women and non-Muslims. The proponents of shari'ah bylaws mostly favor a patriarchal perspective, placing Muslims as the first priority, and ignoring the existence of non-Muslims. Indeed, as Salim wrote, this implies that Muslims' interests must be prioritized over the interests of other religious groups. ${ }^{20}$ As a result, the willingness of religious majority to impose the shari'ah bylaws on all Indonesians will negatively affect the rights of religious minorities.

The claim that Muslims have played the most important role in the struggle against colonial powers also leaves out the role of non-Muslim fighters that is not insignificant. ${ }^{21}$ Historical accounts of Indonesia's independence also clearly acknowledge the contribution of all citizens. Actually, the tyranny of the majority over the minority is common phenomenon that often occurs in many regions in the world. Thus,

17 Pramono U. Tanthowi, "Shari'a and the Fantasy of Nationalism in Post-Soeharto Indonesia," KULTUR: The Indonesian Journal for Muslim Cultures, vol 4, no 2 (2009), pp. 22-23.

18 S. Kamil, "Progressive Shari'a Perspectives of Non-Muslim Minority Rights," KULTUR: The Indonesian Journal for Muslim Cultures, vol 4, no 2 (2009), p. 135.

19 Moeslim Abdurrahman, "Korban Pertama dari Penerapan Syariat adalah Perempuan," www.islamlib.com, 16/9/2001. (Accessed on 6 June 2011).

20 A. Salim, "The Shari'a Bylaws and Human Rights in Indonesia," Studia Islamika, Indonesian Journal for Islamic Studies, vol 15, no 1 (2008), p. 19.

21 Tanthowi, "Shari'a and the Fantasy of Nationalism," p. 23. 
democracy and tolerance were proposed to reduce and avoid this negative phenomenon.

Furthermore, it should be underlined that some aspects of the shari'ah bylaws contravene Indonesia's obligations to protect the right to religious freedom. For example, The instruction of the Major of Padang 451.422/Binsos-III/2005 on the Obligation to Wear the Jilbab and Islamic Dress (for Muslims) and Suggested Attire (for Non Muslims) is certainly shows that the laws discriminate against vulnerable groups. ${ }^{22}$ Although Fauzi Bahar (the Major of Padang) often stated in many occasions that this bylaw does not apply to non-Muslims, anecdotal evidence shows that non-Muslims students are also required to wear the jilbab (veil/female head covering). If non-Muslim students want to ignore this regulation, they are not allowed to attend a class. ${ }^{23}$ As a consequence, a Christian student such as Fransiska Silalahi, had to wear a veil for three years at school. ${ }^{24}$ This type of situation would clearly subject non-Muslims in Padang to social-psychological pressure.

Discrimination against religious minorities not only occurs in Padang, but also in other regions which implement shari'ah bylaws. Research on "The implementation of shari'ah in regional autonomy era: its implications toward civil rights, women rights, and non-Muslim rights" that was conducted by Center for the Study of Religion and Culture (CSRC) of the State Islamic University (Universitas Islam Negeri, UIN) Jakarta provides a useful insight into the reach and impact of shari'ah bylaws. ${ }^{25}$ CSRC studied six regions where shari'a bylaws caused discrimination toward religious minorities. For example, many non-Muslim women were forced to wear Muslim female dress every Friday. Teachers and students at certain High Schools (Sekolah Menengah Umum, SMU) were also required to wear the veil. If they

\footnotetext{
22 Crouch, "Religious Regulations in Indonesia," pp. 81-82.

23 M.G. Romli, "Siswi-siswi Kristen Pun Terpaksa Berjilbab: Kewajiban Busana Muslim' (Even Christrian students have forced to wear veil: Muslim female dress obligation)," Jurnal Perempuan, 2008, http://www.apakabar.ws/content/view/3429/. (Accessed 6 June 2011).

${ }^{24}$ Kamil, "Progressive Shari'a Perspectives,” p. 135.

${ }^{25}$ Kamil, et al., Syariah Islam dan HAM: Dampak Perda Syariab terbadap Kebebasan Sipil, Hak-hak Perempuan dan Non-Muslim (The implementation of Shari'a Islam in regional autonomy era: its implications toward civil rights, women rights, and non-Muslim rights) (Jakarta: CRCS UIN \& KAS, 2007), p. 135.
} 
refused, their parents were required to declare their children as nonMuslims.

Research by the Wahid Institute also states that non-Muslim women in Padang (West Sumatra) and Bulukumba (South Sulawesi) are obliged to wear veil after the implementation of shari'ah bylaws. One of non-Muslim students reported that she felt stressed wearing veil. She thinks that she lives in the community which hates her. This is because most of the people have forced her to obey the regulations that contradict with her religious belief. Besides, her Christian friends have also accused her of converting to Islam because of her decision to wear Muslim female dress. ${ }^{26}$ Hence, one of the Christian leaders in Padang stated that the enactment of shari'ah bylaws had caused a serious psychological problem for non-Muslim students.

Discrimination against religious minorities has also occurred in Aceh, particularly after the implementation of sections of 4 and 5 of Provincial Regulations 5/2000 which regulate standards of dress to all people who live in Aceh, including non-Muslims and tourists. There are many Western women wearing Muslim veils around Banda Aceh. The obligation to wear Muslim female dress was also applied to a Chinese woman working at BCA (secular bank). ${ }^{27}$

Perda No. 5/2003 on the use of the headscarf for Muslim women in Bulukumba (South Sulawesi) takes a different approach. NonMuslims in this area have been told to put on a headscarf at certain events, even though they are not subject of this shari'ah bylaw. One of the respondents of research that was conducted by Rohaiza Ahmad Asi witnessed a situation where outsiders entering Muslim villages were told to put on the headscarf. 28 Relating to this situation, representatives from local community in Bulukumba stated that shari'ah bylaws have already breed intolerance.

The above examples clearly show that shari'ah bylaws that are applied to minorities violate of religious liberties. Besides, the regulations also lack a spirit to protect diversity of people's belief in

\footnotetext{
${ }^{26}$ A. Wahid (ed.), Ilusi Negara Islam: Ekspansi Gerakan Islam Transnasional di Indonesia (the Illusion of Islamic State: Expansion of Islamic Transnational Movements in Indonesia) (Jakarta: LibForAll Foundation, 2009), p. 140.

${ }^{27}$ Kamil, "Progressive Shari'a Perspectives," p. 135

28 Rohaiza Ahmad Asi, Sulawesi: Aspirations of Local Muslims (Singapore: S. Rajaratnam School of International Studies Working Paper series, 2007), pp. 8-12.
} 
Indonesia. Unfortunately, discrimination toward religious minorities continues because even strong non-religious parties frequently use shari'ah bylaws for their religious purposes. As a result, it can be difficult for religious minority groups to find the appropriate agencies which can help them to resist the regulations which disadvantage them. ${ }^{29}$ In fact, shari'ah bylaws not only ignore legal pluralism, but also the fact that Indonesia is a multi-faith community. It is therefore no surprise that the rights of other religious groups are not respected by shari'ah bylaws. ${ }^{30}$

Meanwhile, Pramono U. Tanthowi's research about the application of shari'ah bylaws in Cianjur ${ }^{31}$ also vividly depicts discriminatory practices against non-Muslims. The enactment of shari'ah bylaws in several cases has triggered prejudice and bitter conflict between religious communities. In fact, there are several incidents in which non-Muslims were forced to comply with one or more shari'ah stipulations. For example, individuals including a post office employee, a teacher in a public school, and students of a state high school were forced to wear Muslim dress in the office each Friday. Ironically, shari'ah bylaws in Cianjur are also often used by hard-line Muslim groups to attack property owned by religious minorities. For example, in 2001 hard-line Muslims indiscriminately attacked and demolished non-Muslim restaurants. In other cases, they also expelled several nonMuslim families by forcing them to go to other settlements. ${ }^{32}$ This calls into question claims from proponents of shari'ah bylaws about their respect toward religious minorities. Such claims can, in fact, be seen as little more than political promises, aimed at convincing other groups to believe their agenda without any serious effort at implementation.

It is important to note that discrimination and violations of the rights of religious minorities not only take place in non-Muslim groups, but they also violate the civil liberties of Muslim groups. Such attacks usually target groups which are seen as deviant. Ahmadiyah is one example of an Islamic group which has suffered discrimination

\footnotetext{
${ }^{29}$ Salim, “The Shari'a Bylaws and Human Rights,” pp. 19-20.

30 Ibid., p. 5

31 T.P. Daniels and 'Pramono U. Tanthowi, "Muslims and Tolerance; Non-Muslim Minorities under Sharia in Indonesia," Cont Islam, no. 3 (2009), pp. 317-320.

32 Tanthowi, "Shari'a and the Fantasy of Nationalism," pp. 24-25.
} 
because its followers believe in Mirza Ghulam Ahmad as a prophet. According to a number of shari'ah bylaws, Ahmadiyah damages Islam because it clearly follows the path and concept of apostasy (riddab). The status of apostasy in the shari'ah context not only applies to people who convert from Islam to another religion, but also for people whose and practices deviate from mainstream Islam. ${ }^{33}$ Certainly, this concept is seen as legitimate by a majority of people who live in regions in which shari'a bylaws are implemented. As a result, Ahmadiyah can be seen as having been victimised by some Muslim groups. Ahmadiyah members also are often expelled from their houses and forced to move to other regions.

Another impact of shari'ah bylaws on religious minorities is that many of them face difficulties in building places of worship. For example, although non-Muslims in Cianjur have followed all procedures and fulfilled all requirements to obtain approval to build a place of worship, some Muslim groups remain opposed to their proposal. Similarly, this has also occurred at the national level, as evidenced by the growing numbers of churches and church institutions which have been destroyed by hard-line Muslims. ${ }^{34}$ Interestingly, CSRC's research has confirmed that in areas where shari'ah bylaws apply, non-Muslims often experience damage to their place of worship. Minority Christian groups are forbidden to worship or hear mass in their own homes. This research also reveals that $74 \%$ respondents from non-Muslim groups stated they have experienced difficulties in worshipping. ${ }^{35}$ It can be said that shari'ah bylaws promote intolerance and discrimination against the rights of worship of other groups.

Instead of protecting the rights of religious minorities, some regional governments in Indonesia support discrimination and intolerance toward non-Muslims. This fact can be seen from the local organisational structure in the Ministry of Religious Affairs of Cianjur. The Ministry of Religious Affairs in Indonesia was actually created to deal with religious affairs to all religions. As a result, all religious groups should be represented. Nevertheless, there is no office or officials in charge of non-Muslim services in the Ministry of Religious

\footnotetext{
${ }^{33}$ Kamil, "Progressive Shari’a Perspectives," pp. 142-143.

34 Tanthowi, "Shari'a and the Fantasy of Nationalism," p. 25.

35 Kamil, Syariah Islam dan HAM, pp. 190-194.
} 
Affairs in Cianjur. Non-Muslims have to go to the provincial level of the Ministry of Religious Affairs in Bandung if they encounter problems relating to their religious. ${ }^{36}$ Ironically, this discrimination is not only in terms of service, but also in budgeting matters. Hence, entire budgets are allocated exclusively for Muslims and religious minorities do not receive anything from the Ministry. This situation certainly contradicts the Indonesian constitution which requires neutrality in dealing with all religions.

Shari'ah bylaws in many regions have undermined the civil rights of religious minorities. It has been argued from the CSRC's research that many non Muslims have experienced difficulties in becoming civil servants $(29.5 \%)$, receiving subsidies from local governments $(12 \%)$, and opening places of business during Ramadan (13\%). Besides, some groups have also encountered obstacles in becoming leaders because they are non-Muslims. ${ }^{37}$ Opportunities to become a civil servant are most often accorded to the majority. It is not surprising, because under Islamic rule, non-Muslims cannot be appointed as caliph or president. Shari'ah bylaws also create a paradigm in which non-Muslims' leadership skills and other qualities are seen as inferior to Muslims. Proponents of shari'ah bylaws believe that non-Muslims' status under shari'ah can be understood by looking the concept of dhimmi (nonMuslims under Muslim rule). According to this concept, non-Muslims are allowed to live under Islamic rule and Muslims should regard them religious. Yet, non-Muslims have to obey Islamic law. They also have to pay jizyah (a form of poll tax) to guarantee their loyalty towards the country and the Islamic government protecting their security. ${ }^{38}$

However, the concept of dhimmi (non-Muslims under Muslim rule) has actually been criticized by Islamic scholars. For example, Abdullahi Ahmed an-Na'im argues that shari'ah in the modern era is in fact incompatible with international relations and human rights. ${ }^{39}$ According to him, shari'ah's rigid categorization of territories (där alIslam (Islamic territories) and dàr al-ḩarb (non-Islamic territories) and of

\footnotetext{
36 Tanthowi, "Shari'a and the Fantasy of Nationalism," pp. 27-28.

${ }^{37}$ Kamil, Syariah Islam dan HAM, pp. 201-203.

${ }^{38}$ Nadirsyah Hosen, "Religion and the Indonesian Constitution: A Recent Debate," Journal of Southeast Asian Studies, vol. 36, no. 3 (October 2005), p. 435.

39 Abdullahi A. An-Na'im, "Religious Minorities under Islamic Law and the Limits of Cultural Relativism,” Human Rights Quarterly, vol. 9, no 1 (1987): pp. 1-18.
} 
people (Muslims and dhimmi or non-Muslims) is morally untenable and practically unfeasible in the contemporary world. From non-Muslims' point of view, under the term of dhimmi, they would be the secondclass citizens. Indeed, non-Muslims are afraid that the concept of dhimmi $\bar{i}$ would be applied to them in the future. ${ }^{40}$ Since the rights of religious minorities are not protected by shari'ah bylaws, the implementation of such laws often causes them to feel like outsiders or half citizens. They also feel that their religious liberties are being violated. ${ }^{41}$ In accordance to Indonesia's Constitution, discrimination toward non-Muslims through the concept of dhimm $\bar{i}$ is inconsistent with the notion of equality before the law. Thus, the Indonesian government should protect religious minorities and reevaluate the existence of shari'ah bylaws.

To fully understand the implications of shari'ah bylaws for religious minorities, it is important to consider the views of nonMuslims. Bertholomeus Bolong, for example, has argued that the implementation of shari'ah bylaws can be seen as a 'soft' approach to introducing Islamic law as the basis for the Indonesian state. ${ }^{42}$ Bolong also thinks that the enactment of shari'ah bylaws in a plural and multicultural state like Indonesia will endanger national unity. In fact, the application of shari'ah bylaws can trigger discrimination, intimidation, and force to obey the same regulations as Muslims which in contravention of human rights. This situation can also easily trigger religious conflict in Indonesia. Most Christians in regions where shari'ah bylaws have been implemented have also stated that they feel oppressed by these laws. For example, a Christian in Padang has stated that shari'ah bylaws tend to dismiss the existence of Christian communities and other religious communities outside Islam. In fact, the number of Christians in Padang is approximately 22,000.43 Therefore, the enactment of shari'ah bylaws in this area indirectly

\footnotetext{
40 Nadirsyah Hosen, Shari'a \& Constitutional Reform in Indonesia (Singapore: Institute of Southeast Asian Studies, 2007).

${ }^{41}$ Salim, "Muslim Politics in Indonesia," p. 131.

42 Bertholomeus Bolong "Formalisasi Syariat Islam di Indonesia: Perspektif Gereja Katolik (the formalisation of Shari'a Islam in Indonesia: The perspective of Catholic Church), Al-Mawarid, XIV (2006), pp. 154-156.

${ }^{43}$ Romli, "Siswi-siswi Kristen Pun Terpaksa Berjilbab".
} 
ignores a huge number of people who should have equal rights as other Indonesian citizens.

\section{Some Suggestions for the Protection of Religious Minorities}

As demonstrated above, shari'ah bylaws directly contravene Pancasila and the 1945 Constitution. This is because from the beginning of its independence, Indonesia has adopted an ideology that expresses dedication to Unity in Diversity (Bhinneka Tunggal Ika) and religious pluralism. This ideology, known as Pancasila, does not accord preferential status to the majority. ${ }^{44}$ As a means to fairly meet conflicting demands, Indonesia is neither a religious nor secular state but a Pancasila state. As stated in the 1945 Constitution, Article 29 (1 and 2), "Indonesia is based on The One Mighty God", and "the state guarantees the freedom of religion with the obligation to practice their respected religion". The state recognises equality among citizens irrespective of their religious, ethnic, and gender backgrounds. ${ }^{45}$

As a consequence, the government must be responsible to protect religious minorities from any discrimination by providing them with effective legal remedies. This policy must be emphasized firmly in the constitution. ${ }^{46}$ Because of the importance the rights of minority groupes, the state must evaluate all of the laws which contain discriminatory ideas such as shari' ah bylaws. Besides, the state must make sure that all of the regional regulations correspond with the principle of nationality, plurality, equality, tolerance, and justice. According to R.E. Elson, ${ }^{47}$ great political morality and will are required to make this a reality. This is likely to be challenging, however, given that politics often prioritises pragmatism over moral considerations.

It is important to note that many shari'ah bylaws reflect a narrow, text-based and traditional interpretation of shari'ah. As a consequence, religious minorities and other Muslim groups which have different opinions from the hard-line Islamic groups often become the victims of such interpretation. Besides, the formalisation of shari'ah through bylaws frequently only represents shari'ah in the form of its formalistic

\footnotetext{
${ }^{44}$ Eliraz, Islam in Indonesia, pp. 78-79.

${ }^{45}$ Hara, "Pancasila and the Perda Syari'ah Debates," p. 39.

${ }^{46}$ Salim, "Muslim Politics in Indonesia," p. 135.

47 R. E. Elson, "Nationalism, Islam, 'Secularism' and the State in Contemporary Indonesia," Australian Journal of International Affairs, vol 64, no 3 (2010), p. 340
} 
sense, without applying its substantive meaning. In fact, the substantive meaning of shari'ah is to encourage peace, justice, humanity, wisdom, and prosperity. ${ }^{48}$ As Nadirsyah Hosen has noted, under the substantive shari'ah approach, the flexibility of Islamic law is assured and citizens' constitutional rights are guaranteed. ${ }^{49}$ Therefore, Muslims should consider the substantive approach to shari'ah and show that shari'ah does not necessarily cause political chaos or inflict harm upon religious minorities.

\section{Conclusion}

Shari'ah bylaws represent an old agenda which emerged again during the regional autonomy era. The regional autonomy agenda which was intended to increase the effectiveness and efficiency of bureaucracy has often been misused by local leaders to create shari'ah bylaws. This is because many local leaders view shari'ah bylaws as an opportunity to strengthen their power. The enactment of shari'ah bylaws also represents a renewed attempt of formalization of shari'ah at the regional level, after their failure to do so through open democratic processes at the national level. Besides, Aceh's success in implementing shari'ah bylaws has also triggered greater interest in shari'ah bylaws in other regions.

The introduction of such bylaws has many negative implications for religious minorities in Indonesia. This is because people of religious minorities are forced to observe the same regulations as the so-called maintsream Muslims. Shari'ah bylaws have also caused discrimination against religious minorities. In many regions in which shari'ah bylaws have been implemented, religious minorities have lost their rights to religious freedom, peaceful worship, and appropriate living. Indeed, the status of non-Muslims under shari'ah bylaws can potentially place them as the second-class citizens. In order to stop the negative implications of shari'ah bylaws, the Indonesian government should protect religious minorities' rights through the Constitution which must be obeyed by all Indonesians. At the same time, Muslims should

\footnotetext{
${ }^{48}$ M. Wahid, "Syariat Islam, Negara, dan Ancaman Pluralitas: Kritik atas Perda 'Syariat Islam' di Indonesia" (Shari'a Islam, State, and Threat of Plurality: The Critiques of Shari'a Bylaws in Indonesia), Tasbwirul Afkar, no 20 (2006).
}

${ }^{49}$ Hosen, Shari'a \& Constitutional Reform, p. 233. 
also consider the true meaning and substance of shari'ah, rather than only focusing on its formal implementation. []

\section{Bibliography}

\section{Books and Articles}

Abdurrahman, M. "Korban Pertama dari Penerapan Syariat adalah Perempuan (the First Victim of the Application of Shari'a Bylaws is Women). www.islamlib.com, 16/9/2001. Accessed on 6 June 2011.

Asi, R.A. Sulawesi: Aspirations of Local Muslims. Singapore: S. Rajaratnam School of International Studies Working Paper series, 2007.

An-Na'im, A.A. "Religious Minorities under Islamic Law and the Limits of Cultural Relativism." Human Rights Quarterly. vol 9, no 1 (1987): pp. 1-18.

Assyaukanie, Luthfi. "The Rise of Religious Bylaws in Indonesia." RSIS Commentaries (22/2007).

Bolong, B. "Formalisasi Syariat Islam di Indonesia (Perspektif Gereja Katolik) (the formalisation of Shari'a Islam in Indonesia (the perspective of Catholic Church). Al-Mawarid. XIV (2006): pp. 146-161.

Buehler, M. “The Rise of Shari'a Bylaws in Indonesian Districts: An Indication for Changing Patterns of Power Accumulation and Political Corruption." South East Asia Research, vol 16, no 2 (2008): pp. 255-285.

Bush, Robin, "Regional Sharia Regulations in Indonesia: Anomaly or Sympton?." in G. Fealy and S. White (eds). Expressing Islam: Religious Life and Politics in Indonesia. Singapore: Institute of Southeast Asian Studies (2008): pp. 174-191.

Crouch, M. "Religious Regulations in Indonesia: Failing Vulnerable Groups." Review of Indonesian and Malaysian Affairs, vol 43, no 2 (2009): pp. 53-103.

Daniels, T.P., Pramono U. Tanthowi. "Muslims and tolerance; NonMuslim minorities under Sharia in Indonesia." Cont Islam, no 3 (2009): pp. 317-320. 
Eliraz, G. Islam in Indonesia: Modernis, Radicalism, and the Middle East Dimension. Brighton \& Portland: Sussex Academic Press, 2004.

Elson, R.E. 'Nationalism, Islam, 'Secularism' and the State in Contemporary Indonesia." Australian Journal of International Affairs, vol 64, no 3 (2010): pp. 328-343.

Erb, M. et al. (eds). Regionalism in Post-Suharto Indonesia. London and New York: RoutledgeCurzon, 2005.

Hara, A.E. "Pancasila and the Perda Syari'ah Debates in the PostSuharto Era: Toward a New Political Consensus." in O. Atsushi et al. (eds). Islam In Contention: Rethinking Islam and State in Indonesia. Jakarta: The Wahid Institute - Japan: CSEAS Taiwan: CAPAS (2010): pp. 35-75.

Hasan, N. "Islamic Militancy, Shari'a Bylwas, and Democratic Consolidation in Post-Suharto Indonesia." KULTUR: The Indonesian Journal for Muslim Cultures, vol 4, no 2 (2009): pp. 3361.

Hosen, Nadirsyah. "Religion and the Indonesian Constitution: A Recent Debate." Journal of Southeast Asian Studies, vol 36, no 3 (October 2005): pp. 419-440.

-. Shari'a \& Constitutional Reform in Indonesia. Singapore: Institute of Southeast Asian Studies, 2007.

Kamil, S. "Progressive Shari'a Perspectives of Non-Muslim Minority Rights." KULTUR: The Indonesian Journal for Muslim Cultures, vol 4, no 2 (2009): pp. 133-157.

-, et al. Syariah Islam dan HAM: Dampak Perda Syariah terhadap Kebebasan Sipil, Hak-hak Perempuan, dan Non-Muslim (The implementation of Shari'a Islam in regional autonomy era: its implications toward civil rights, women rights, and non-Muslim rights). Jakarta: CRCS UIN \& KAS, 2007.

Mulia, Siti Musda. "Perda Syariat and Peminggiran Perempuan." (The Marginalization of Women within Sharia Regulations) Tashwirul Afkar, no 20 (2006): pp. 21-44.

Romli, M.G. "Siswi-siswi Kristen Pun Terpaksa Berjilbab: Kewajiban Busana Muslim." (Even Christian Students have Forced to Wear Veil: Muslim Female Dress Obligation) Jurnal Perempuan, 2008. 
http://www.apakabar.ws/content/view/3429/. Accesed on 6 June 2011.

Salim, A. "Muslim Politics in Indonesia's Democratization: The Religious Majority and the Rights of Minorities in the Post-New Order Era." in R.H. McLeod and A. MacIntyre (eds). Indonesia: Democracy and the Promise of Good Governance. Singapore: Institute of Southeast Asian Studies (2007): pp. 35-75.

------. "The Shari'a Bylaws and Human Rights in Indonesia." Studia Islamika, Indonesian Journal for Islamic Studies, vol 15, no 1 (2008): pp. 1-23.

Tanthowi, P.U. "Shari'a and the Fantasy of Nationalism in PostSoeharto Indonesia." KULTUR: The Indonesian Journal for Muslim Cultures, vol 4, no 2 (2009): pp. 19-32.

Wahid, A. (ed.). Ilusi Negara Islam: Ekspansi Gerakan Islam Transnasional di Indonesia. (the Illusion of Islamic State: Expansion of Islamic Transnational Movements in Indonesia) Jakarta: LibForAll Foundation, 2009).

Wahid, M. "Syariat Islam, Negara, dan Ancaman Pluralitas: Kritik atas Perda 'Syariat Islam di Indonesia." (Shari'a Islam, state, and threat of plurality: the critiques of shari'a bylaws in Indonesia) Tashwirul Afkar, no. 20, 2006. 